\title{
Maternal assessment of pain in premature infants
}

\author{
Avaliação materna da dor em recém-nascidos prematuros \\ Evaluación materna del dolor en recién nacidos prematuros
}

Maria Carolina Correia dos Santos ${ }^{1}$, Maria Fernanda Pereira Gomes ${ }^{1}$, Verusca Kelly Capellini ${ }^{1}$, Valéria Cristina dos Santos Carvalho ${ }^{1}$

Objective: to identify mothers' perceptions about the pain in their premature babies in the Neonatal Intensive Care Unit. Methods: evaluative, quantitative study with investigative nature conducted with 19 mothers of hospitalized premature newborns. Data were obtained from closed questions, answered by mothers. Results: from the participants, two (10.5\%) reported that newborns are unable to feel pain. From the 17 mothers who said that premature babies can feel pain, the majority (94.1\%) identified crying as a characteristic of pain sensation. Eleven (64.7\%) stated that uneasiness is a sign of pain in newborns. Conclusion: for the proper management of neonatal pain it is essential that mothers know the signs of pain in premature newborns, and that health professionals instruct this recognition, through the enhancement of the maternal presence and practice of effective communication between professionals and newborns' families.

Descriptors: Acute Pain; Infant, Newborn; Infant, Premature; Pain Measurement.

Objetivo: identificar a percepção das mães sobre a dor de seus filhos prematuros internados na Unidade de Terapia Intensiva Neonatal. Métodos: pesquisa avaliativa, quantitativa e de cunho investigativo com 19 mães de recém-nascidos prematuros hospitalizados. Os dados foram obtidos através de questões fechadas, preenchidas pelas mães. Resultados: das participantes, duas (10,5\%) referiram que os recém-nascidos são incapazes de sentir dor. Das 17 mães que afirmaram que o prematuro sente dor, a maioria $(94,1 \%)$ identificou o choro como característica de sensação dolorosa. Onze $(64,7 \%)$ afirmaram que a agitação é um sinal de dor no recém-nascido. Conclusão para o adequado manejo da dor neonatal é essencial que as mães conheçam os sinais de dor nos recém-nascidos prematuros, e que os profissionais de saúde as instruam neste reconhecimento, por meio da valorização da presença materna e a prática de uma comunicação eficaz entre os profissionais e a família do recém-nascido.

Descritores: Dor Aguda; Recém-Nascido; Prematuro; Medição da Dor.

Objetivo: identificar la percepción de madres sobre el dolor de hijos prematuros en Unidad de Cuidados Intensivos Neonatales. Métodos: investigación evaluativa, cuantitativa y de investigación con 19 madres de recién nacidos prematuros hospitalizados. Datos obtenidos a partir de preguntas cerradas, llenas por las madres. Resultados: de las participantes, dos (10,5\%) informaron que recién nacidos son incapaces de sentir dolor. De las 17 madres que dicen que el prematuro siente dolor, la mayoría $(94,1 \%)$ identificó el lloro como característico de sensación de dolor. Once $(64,7 \%)$ declararon que la crisis es un signo de dolor en recién nacido. Conclusión: para el manejo adecuado del dolor neonatal es esencial que las madres conozcan los signos de dolor en recién nacidos prematuros, y que los profesionales de salud las instruya a este reconocimiento, a través de la valoración de la presencia materna y práctica de comunicación efectiva entre profesionales y familia del recién nacido.

Descriptores: Dolor Agudo, Recién Nacido; Prematuro; Dimensión del Dolor.

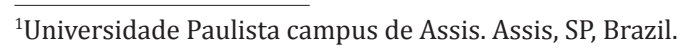

Corresponding author: Maria Fernanda Pereira Gomes

Rua Amador Bueno 821, Casa 2, Vila Ebenezer, CEP: 19807-170, Assis, SP, Brazil. E-mail: mferpg@usp.br 


\section{Introduction}

Neonatal intensive care has been modified in recent decades both from a technological point of view, as well as from scientific evidence that has provided significant improvements for preterm infants' care and for their families ${ }^{(1)}$.

In this regard, the survival of premature infants has increased, allowing newborns with extreme gestational age and/or very low weight at birth to survive $^{(1)}$. In the possibility of premature newborns surviving hospitalization in neonatal intensive care units, it is fundamental to exclude and/or mitigate the determining risk factors of the clinical picture they are $\operatorname{in}^{(1)}$.

For families and especially for mothers, the birth of a premature baby has the potential to produce significant emotional repercussions. Mothers usually experience ambivalent feelings about their premature newborns, usually due to their biological vulnerability condition. The joy for the child's birth is often invaded by feelings of grief, frustration and incompetence by the newborn fragility, which lead to significant changes in the family dynamics( ${ }^{(2)}$.

The weaknesses of premature infants bring with them the questions of maternal perceptions about care for their premature children ${ }^{(2)}$. Another important point to note is that newborns when hospitalized experience painful sensations. Pain is always associated with some condition that the child can present and some procedures that may be performed. Therefore, it is important that mothers are oriented about neonatal pain.

During hospitalization newborns go through about 50 to 150 potentially painful procedures. Preterm premature newborns weighing less than $1000 \mathrm{~g}$ suffer about 500 or more painful interventions during hospitalization ${ }^{(3)}$.

Pain is considered an unpleasant feeling that can be defined as a sensitive, emotional, subjective and unpleasant experience associated with real or potential injury of a tissue ${ }^{(3)}$.
In this context, assessing pain in a newborn is a major obstacle to families and health care teams. Pain is considered the "fifth vital sign", which also makes us assess pain during every vital signs check. This way the infant will be periodically evaluated and if necessary interventions will be held with him $^{(4)}$.

In premature infants, the early verbal communication is missing, which makes the diagnosis of pain more difficult ${ }^{(5)}$. There are some instruments which evaluate physiological and behavioral changes that can assist in the qualification and quantification of pain ${ }^{(5)}$.

In order to relieve pain in neonates there are pharmacological and non-pharmacological interventions ${ }^{(5)}$. Pharmacological interventions are carried out through pre-established drugs prescribed by the doctor. Non-pharmacological interventions are designed to prevent or lessen the intensity of the painful process ${ }^{(5)}$.

In this sense the environment in which infants are kept should be as quiet as possible, reducing the lighting so that it does not cause stress and moving the child as little as possible. The change of position should be held when necessary for changing positions and contact should always be encouraged between mother and child(6).

Many mothers do not know that their babies who were taken into the neonatal intensive care unit feel pain, because of their size and short time of life. The main focus of this article is to know the way that mothers see the pain in their hospitalized children and describe how they observe the presence of pain.

In this perspective the objective of this study is to identify mothers' perception about the pain of their premature children in a neonatal intensive care unit.

\section{Method}

This is an evaluative, quantitative study of investigative nature, which seeks to elucidate the maternal perception about neonatal pain.

It was used as the samples of this study all the 
mothers with hospitalized children in the neonatal intensive care unit in the period from June to July 2014. Out of the 22 mothers present in the survey period, 19 participated in the study. The number of mothers who participated in the survey was reduced because the occupancy rate of premature babies in the unit was smaller and there were some babies who were born extremely premature and were hospitalized for a long period, reducing the turnover of beds in the sector.

The data collection was conducted through a questionnaire of closed questions that was available to mothers at the time they were going to visit their children. The questionnaire was constructed based on the scientific document of the Department of Neonatology of the Brazilian Society of Pediatrics, The Language of Pain in Newborns ${ }^{(7)}$. The questions are closed and allow one to identify if mothers think that the signs: crying, restlessness, being quiet, refusing to breastfeed, open mouth, stretched mouth, tense language, tongue protrusion, protruding forehead, closed eyes, deep nasolabial fold and chin tremor are indicators of pain or not.

The data were organized and analyzed with the help of the Microsoft Excel software. The study was approved by the Ethics and Research Committee under opinion No 1,032,950. It was also authorized by the hospital's health manager. Mothers who agreed to participate received and signed the Free and Informed Consent Form, prepared according to the Resolution $466 / 12$.

\section{Results}

Most of the mothers who participated in the survey agreed that premature newborns feel pain. Out of the 19 mothers who participated in the survey; 9 are mothers of premature babies who were first-born and premature; 5 mothers had already had other premature children; and the other five mothers had other children, however, the hospitalized newborn is their first child born with prematurity.

Table 1 shows the pain signals identified by mothers of premature newborns as follows: when he cries, when he gets restless, very quiet, refuses the breastfeed, open mouth, stretched mouth, tense tongue, tongue protrusion, protruding forehead, closed eyes, deep nasolabial fold and chin trembling.

Table 1 - Pain signals indicated by mothers of premature newborns

\begin{tabular}{lc}
\hline Pain signals & n (\%) \\
\hline Crying & $17(94.1)$ \\
Restlessness & $11(64.7)$ \\
Quiet & - \\
Refuses to breastfeed & $4(23.5)$ \\
Open mouth & $1(3.9)$ \\
Stretched mouth & - \\
Tense tongue & - \\
Tongue protrusion & - \\
Protruding forehead & $2(11.8)$ \\
Closed Eyes & $4(23.5)$ \\
Deep nasolabial fold & - \\
Chin tremor & $4(23.5)$ \\
Total & $19(100.0)$ \\
\hline
\end{tabular}

For a proper pain management in the neonatal intensive care unit it is essential to identify signs of pain in premature newborns both by mothers and professionals.

\section{Discussion}

The results show that most mothers believe their newborn children feel pain, with the exception of only two mothers, who believe their children are unable to feel pain.

These results are in agreement with studies about pain in newborns, studies that have been evolving since the mid-80s of the last century. Currently it is fully accepted that both term and preterm newborns have all the anatomical, functional and neurochemical structures, which are essential for nociception, ie for the reception, transmission and 
integration of painful stimuli ${ }^{(6)}$.

Because of the benefits obtained in relation to the progress of the newborn, the active participation of family members, especially parents, should be encouraged and facilitated by the hospital and by the health team ${ }^{(8)}$.

Pain assessment is a nursing responsibility, which through some mechanisms identify the painful manifestations and their characteristics, which are important tools in the care of premature newborns. In this context, it is important to highlight that the signals of pain that mothers see in their children can help in the nursing care $\mathrm{e}^{(4,6)}$.

Pain relief and comfort promotion are essential interventions that involve, in addition to scientific knowledge and technical skill, humanitarian and ethical nursing practice. The importance of the study of pain is due to the fact that this feeling creates stress, suffering and discomfort for patients and their families ${ }^{(9)}$.

The painful signal most mentioned by mothers was crying. When crying is caused by pain, it happens in a sharper tone. The melodic pattern of crying and its frequency are around 80 decibels. Studies show that crying of pain has unique characteristics: sudden onset without previous moans ${ }^{(10)}$.

Crying was also pointed as the main pain signal by parents surveyed in a study about pain conducted at neonatal intensive care units in the city of Rio de Janeiro. The characteristics of crying and the babies' behavior are sources of information about their health for mothers. Behavioral changes help mothers identify where the pain occurs ${ }^{(11)}$.

Other parameters were also asked to mothers, such as restlessness that was the second most mentioned signal of pain, because many mothers believe that when their children are very agitated they may be having some painful abnormalities ${ }^{(10)}$.

There are also behavioral responses involving the emotional part of the premature newborn, such as changes in eating habits, which was also mentioned by mothers who believe that, when their children are in pain, they refuse to breastfeed.

Facial expressions are one of the mostcommonly used ways in the study of perception of neonatal pain $^{(12-13)}$. Facial changes are the main elements in the study of pain in premature newborns, because in this age group facial expressions express more accurately the pain. Around $95-98 \%$ of premature newborns have at least three indicatives of pain, such as: protruding forehead, deep nasolabial fold and chin trembling as indicative of pain ${ }^{(12)}$.

Neonatal pain is recognized by behavioral and physiological changes. In a study conducted in the neonatal intensive care unit of Ribeirão Preto, in relation to behavioral manifestations, professionals identify facial expressions and crying as the main signals shown ${ }^{(14)}$.

In a study conducted in a neonatal intensive care unit in the city of Maringá, PR, it was identified that there is vulnerability in the knowledge of nursing professionals who work in the neonatal intensive care unit regarding pain and analgesia of newborns, essential aspects to the understanding of the need to identify and treat this phenomenon that is so complex, although they identify and use strategies for its control ${ }^{(15)}$. Perhaps this is related to the deficiency of the study of this issue during professional training, making it difficult, therefore, that intervention measures occur for pain management ${ }^{(15)}$. The lack of assessment protocols and pain treatment also confirms the limitation of their identification and management ${ }^{(15-16)}$.

Nursing professionals can minimize the stress and pain of premature newborns through minimal touching, talking and manipulation in order to reduce the stress and reduce the possibilities of deficit in the development ${ }^{(17)}$. Another point to make is that it is important for mothers to be included in the participation of their children's care identifying signals of pain, neonatal stress and talking to the nursing staff.

The maternal look is unique in the hospitalization of premature newborns, and it is at 
this moment that the authentic relationship between mother and son is characterized, which occurs when the mother puts herself in the place of her child, a phenomenon that affects her directly.

Mothers who experience difficulties to visit their children are more sensitive to how they are treated by nursing professionals and by the health team in general; therefore, unfavorable and/or unreceptive behaviors make them visit their children even less ${ }^{(8)}$.

For this reason it is necessary that there is an open dialogue between nursing and mothers. The humanistic look occurs at the moment when we put ourselves in the place of mothers, this way understanding the changes that may appear, such as behavioral and expression changes, respecting the opinion of mothers who can be allies in our daily nursing practice ${ }^{(18)}$.

Pain management in neonatology includes three types of interventions: environmental, behavioral and pharmacological ${ }^{(11)}$. Non-pharmacological interventions would be the ones related to attitudes such as changing the position, wrapping the newborn in bedsheets, holding him and encouraging mothers to provide the kangaroo care; the non-nutritive sucking and breastfeeding during painful procedures, facilitating the organization and auto-regulation of preterm neonates ${ }^{(11)}$. The parents interviewed in a study conducted in a neonatal intensive care unit of Rio de Janeiro reported that for them the care that can minimize their children's pain are transmitting maternal warmth, holding them and putting them close to their chest $^{(11)}$.

For nursing care to be humanized and use mothers in its practice it is necessary that both professionals and mothers are oriented about pain signals for some paradigms to be broken as confirmed by a study conducted in 2011 in a neonatal intensive care unit in Assis-SP, in which it was observed that healthcare professionals recognize that newborns feel pain and that it is necessary to treat $\mathrm{it}^{(6)}$. However, there is still a big gap for the proper application of knowledge, because it is noticed that professionals often fail to assess, mitigate, prevent and treat acute pain resulting from potentially painful procedures. Thus, awareness and professional training actions should be implemented, providing continuing education to caregivers and making them active subjects in the evaluation and treatment of neonatal pain $^{(19)}$.

\section{Conclusion}

According to the results most mothers recognize that their children feel pain and recognize that they have their own particular mechanisms and to express this pain. It was possible to demonstrate the importance of the maternal look to treat premature infants because the contact between mother and baby is an intense and strong bond, which favors the practice of nursing in the identification, evaluation and treatment of neonatal pain.

For the proper management of neonatal pain it is essential that mothers know the signals of pain in premature newborns, and that health professionals instruct this recognition, through the enhancement of the maternal presence and the practice of effective communication between professionals and the newborn's family. In addition, it is important that health professionals value the reports of mothers and the signals they identified that are related to their children, ensuring humanized and comprehensive care.

\section{Collaborations}

Santos MCC, Gomes MFP and Capellini VK contributed to the creation, collection of field data, analysis, data interpretation and writing of the article. Carvalho VCS contributed to the creation, analysis, writing and final approval of the version to be published. 


\section{References}

1. Marques SL, Pereira MP, Santos LFN, Santana RCB. Avaliação da dor no recém-nascido prematuro em Unidade de Terapia Intensiva. Rev Bras Enferm. 2012; 65(1):27-33.

2. Anjos LS, Lemos DM, Antunes LA, Andrade JMO, Nascimento WDM, Caldeira AP. Percepções maternas sobre o nascimento de um filho prematuro e cuidados após a alta. Rev Bras Enferm. 2012; 65(4):571-7.

3. Tamez RN, Silva MJP. Enfermagem na UTI neonatal: assistência ao recém nascido de alto Risco. Rio de Janeiro: Guanabara Koogan; 2013.

4. Ministério da Saúde (BR). Secretaria de Atenção à Saúde. Departamento de Ações Programáticas Estratégicas. Atenção à saúde do recém-nascido: guia para os profissionais de saúde. Brasília Ministério da Saúde; 2013.

5. Nascimento JCC, Silva LCS. Avaliação da dor em pacientes sob cuidados em Unidades de Terapia Intensiva: uma revisão de literatura. Rev Movimenta. 2014; 7(2):711-20.

6. Capellini VK, Daré MF, Castral TC, Christoffel MM, Leite AM, Scochi CGS. Conhecimento e atitudes de profissionais de saúde sobre avaliação e manejo da dor neonatal Rev Eletr Enf [Internet]. 2014 [citado 2015 mar 17];6(2). Disponível em: https://www.fen.ufg.br/fen_revista/v16/n2/ pdf/v16n2a12.pdf

7. Sociedade Brasileira de Pediatria. Departamento de Neonatologia. Documento Científico: A linguagem da dor no recém-nascido. Rio de Janeiro; 2010.

8. Carmona EV, Vale IN, Ohara CVS, Abrao ACFV. Percepção materna quanto aos filhos recémnascidos hospitalizados. Rev Bras Enferm. 2014; 67(5):788-93.

9. Santos MZ, Kusahara DM, Pedreira MLG. The experiences of intensive care nurses in the assessment and intervention of pain relief in children. Rev Esc Enferm USP. 2012; 46(5):107481.

10. Segre CAM. Perinatologia fundamentos e prática. São Paulo: Sarvier; 2002.
11. Pacheco STA, Duffrayer LR, Pacheco MD, Araújo BBM. O manejo da dor em recém-nascidos prematuros sob a ótica dos pais uma contribuição para enfermagem. Rev Pesqui Cuid Fundam Online. [Internet]. 2013 [citado 2015 mar 17]; 5(1):3352-59. Disponível em: http://pesquisa. bvs.br/brasil/resource/pt/bde-24224

12. Maia ACA, Coutinho SB. Fatores que influenciam a prática do profissional de saúde no manejo da dor do recém-nascido. Rev Paul Pediatr. 2011; 29(2):270-6.

13. Bottega FH, Benetti ERR, Benetti PE, Gomes JS, Stumm EMF. Avaliação da dor em neonatos e crianças em terapia intensiva. Rev Pesqui Cuid Fundam Online. [Internet]. 2014 [citado $2015 \mathrm{mar}$ 17]; 6(3):909-17. Disponível em: http://www. seer.unirio.br/index.php/cuidadofundamental/ article/viewFile/3115/\%20pdf_1331

14. Santos LM, Ribeiro IS, Santana RCB. Identificação e tratamento da dor no recém-nascido prematuro na Unidade de Terapia Intensiva. Rev Bras Enferm. 2012; 65(2):269-75.

15. Veronez M, Corrêa DAM. A dor e o recémnascido de risco: percepção dos profissionais de enfermagem. Cogitare Enferm. 2010; 15(2):26370.

16. Cordeiro RA, Costa R. Métodos não farmacológicos para alívio do desconforto e da dor no recémnascido: uma construção coletiva da enfermagem. Texto Contexto Enferm. 2014; 23(1):185-92.

17. Balbino AC, Cardoso MVLML, Silva RCC, Moraes KM. Recém-nascido pré-termo: respostas comportamentais ao manuseio da equipe de enfermagem. Rev Enferm UERJ. 2012; 20(n. esp.):615-20.

18. Ministério da Saúde (BR). Secretaria de Políticas de Saúde. Área de Saúde da Criança. Atenção humanizada ao Recém-Nascido de baixo peso: método mãe canguru. Brasília: Ministério da Saúde; 2002.

19. Monfrim XM, Saraiva LA, Moraes CL, Viegas AC. Escala de avaliação da dor: percepção dos enfermeiros em uma Unidade de Terapia Intensiva Neonatal. Rev Enferm UFSM. 2015; 5(1):12-22. 